\title{
Research on Teaching Quality Evaluation in Applied Undergraduate Universities
}

\author{
Rong Chen \\ School of Physics and Electronic Information, Nanchang Normal University, Nanchang, China \\ Email: xinseafank@163.com
}

How to cite this paper: Chen, R. (2021). Research on Teaching Quality Evaluation in Applied Undergraduate Universities. Creative Education, 12, 2322-2327.

https://doi.org/10.4236/ce.2021.1210175

Received: September 15, 2021

Accepted: October 15, 2021

Published: October 18, 2021

Copyright (c) 2021 by author(s) and Scientific Research Publishing Inc. This work is licensed under the Creative Commons Attribution International License (CC BY 4.0).

http://creativecommons.org/licenses/by/4.0/

\begin{abstract}
In order to further implement the concept of "student-centered, output oriented and continuous improvement" and improve the level of education and teaching, teaching quality evaluation has been carried out. It aims to understand students' learning status and learning satisfaction, and help teachers and students make continuous improvement. Constructing the prediction model of curriculum system satisfaction and finding out the biggest factor affecting the prediction model are teaching feedback. Put forward the path to improve the teaching quality, and implement and evaluate the effect in teaching.
\end{abstract}

\section{Keywords}

Teaching Quality, Curriculum Teaching, Evaluation, Teaching Level

\section{Introduction}

In applied undergraduate universities, teachers can grasp the actual teaching situation and teaching effect through teaching quality evaluation. It can also make students understand their actual learning situation and learning effect. Combining qualitative analysis with quantitative analysis, teaching quality evaluation can grasp the problems existing in teaching, put forward data-based solutions to these problems, and improve and optimize the teaching level of colleges and universities.

\section{Overall Situation of Teaching Quality Evaluation}

In the professional dimension, two undergraduate majors and one junior major are selected, which are physics, electronic information engineering and electronic information engineering technology. The number of undergraduate students majoring in physics should participate in the evaluation is 2743 , the number of ac- 
tual participants is 2661 , the participation rate is $97.89 \%$, and the comprehensive score of the curriculum system is 89.36 . The number of undergraduate students majoring in electronic information engineering should participate in the evaluation is 4218 , the number of actual participants is 3891, the participation rate is $95.64 \%$, and the comprehensive score of the curriculum system is 88.96 . The number of junior college students majoring in electronic information engineering technology should participate in the evaluation is 1618 , the number of actual participants is 1504 , the participation rate is $97.96 \%$, and the comprehensive score of the curriculum system is 81.67 , as shown in Table 1 .

\section{Analysis of Curriculum Teaching Dimensions}

Curriculum teaching is divided into ten dimensions, which are as follows: degree of difficulty, curriculum ideological and political, teacher-student interaction, class evaluation, teaching means, curriculum resources, teaching organization, curriculum assessment, teaching feedback and curriculum satisfaction. Five options are set for each dimension: very agree (10 points), agree ( 7.5 points), general ( 5 points), disagree (2.5 points) and very disagree ( 0 points).Now, the full score of each dimension is converted into a 5-point five-level Likert scale through formula (1). Formula (1) is as follows

$$
x=(x+2.5) / 2.5
$$

The five options after conversion are very agree ( 5 points), agree ( 4 points), general ( 3 points), disagree ( 2 points) and very disagree ( 1 point).Then make quantitative analysis on the teaching dimensions of the curriculum. The mean and variance are shown in Table 2 . It can be seen from Table 2 that the average value of the ten dimensions of curriculum teaching is between very agree and agree, indicating that students have a high degree of identification with the ten dimensions of curriculum teaching.

\section{Correlation Analysis between Curriculum Teaching Dimensions}

It can be seen from Table 3 that the $\mathrm{P}$ values of the ten dimensions of curriculum teaching are 0.000 , all less than 0.05 , indicating a significant correlation. The ten dimensions of curriculum teaching do not conform to the normal distribution,

Table 1. Overall situation of professional evaluation.

\begin{tabular}{|c|c|c|c|c|c|c|}
\hline Major & $\begin{array}{c}\text { Educational } \\
\text { level }\end{array}$ & Type & $\begin{array}{l}\text { Number of } \\
\text { participants }\end{array}$ & $\begin{array}{l}\text { Number of actual } \\
\text { participants }\end{array}$ & $\begin{array}{l}\text { Participation } \\
\text { rate }\end{array}$ & $\begin{array}{l}\text { Comprehensive score } \\
\text { of curriculum system }\end{array}$ \\
\hline physics & undergraduate & normal class & 2743 & 2661 & $97.89 \%$ & 89.36 \\
\hline $\begin{array}{l}\text { electronic information } \\
\text { engineering }\end{array}$ & undergraduate & non normal class & 4218 & 3891 & $95.64 \%$ & 88.96 \\
\hline $\begin{array}{l}\text { electronic information } \\
\text { engineering technology }\end{array}$ & specialty & non normal class & 1618 & 1504 & $97.96 \%$ & 81.67 \\
\hline
\end{tabular}


Table 2. Mean value of curriculum teaching dimensions.

\begin{tabular}{cc}
\hline Dimension & Mean \pm SD \\
\hline Degree of Difficulty & $4.53 \pm 0.651$ \\
Curriculum ideological and political & $4.52 \pm 0.653$ \\
Teachers-students interaction & $4.51 \pm 0.663$ \\
Class evaluation & $4.52 \pm 0.661$ \\
Teaching Means & $4.50 \pm 0.675$ \\
Curriculum resources & $4.51 \pm 0.660$ \\
Teaching organization & $4.51 \pm 0.663$ \\
Curriculum Assessment & $4.52 \pm 0.655$ \\
Teaching feedback & $4.52 \pm 0.648$ \\
Curriculum satisfaction & $4.49 \pm 0.662$ \\
\hline
\end{tabular}

Table 3. Correlation coefficient of spearman.

\begin{tabular}{|c|c|c|c|c|c|c|c|c|c|c|}
\hline & 1 & 2 & 3 & 4 & 5 & 6 & 7 & 8 & 9 & 10 \\
\hline 1. Degree of difficulty & 1.000 & $0.887^{\star *}$ & $0.862^{\star *}$ & $0.847^{\star *}$ & $0.827^{\star *}$ & $0.839^{\star *}$ & $0.839^{\star *}$ & $0.834^{\star *}$ & $0.826^{* *}$ & $0.822^{\star *}$ \\
\hline $\begin{array}{l}\text { 2. Curriculum ideological } \\
\text { and political }\end{array}$ & $0.887^{\star \star}$ & 1.000 & $0.887^{\star *}$ & $0.864^{\star *}$ & $0.850^{* *}$ & $0.847^{\star *}$ & $0.852^{\star *}$ & $0.850^{* *}$ & $0.839^{* *}$ & $0.846^{\star *}$ \\
\hline $\begin{array}{l}\text { 3. Teachers-students } \\
\text { interaction }\end{array}$ & $0.862^{\star *}$ & $0.887^{\star *}$ & 1.000 & $0.880^{* *}$ & $0.860^{* *}$ & $0.863^{\star \star}$ & $0.858^{\star *}$ & $0.853^{\star *}$ & $0.845^{\star *}$ & $0.846^{\star \star}$ \\
\hline 4. Class Evaluation & $0.847^{\star *}$ & $0.864^{\star *}$ & $0.880^{* *}$ & 1.000 & $0.871^{\star *}$ & $0.864^{* *}$ & $0.858^{\star *}$ & $0.851^{\star *}$ & $0.844^{* *}$ & $0.848^{\star *}$ \\
\hline 5. Teaching means & $0.827^{\star *}$ & $0.850^{* *}$ & $0.860^{* *}$ & $0.871^{\star *}$ & 1.000 & $0.876^{\star *}$ & $0.864^{* *}$ & $0.849^{* *}$ & $0.848^{* *}$ & $0.847^{\star *}$ \\
\hline 6. Curriculum resources & $0.839^{* *}$ & $0.847^{\star *}$ & $0.863^{* *}$ & $0.864^{\star *}$ & $0.876^{\star *}$ & 1.000 & $0.887^{\star *}$ & $0.863^{* *}$ & $0.855^{\star *}$ & $0.853^{\star *}$ \\
\hline 7. Teaching organization & $0.839^{\star *}$ & $0.852^{* *}$ & $0.858^{\star *}$ & $0.858^{* *}$ & $0.864^{* *}$ & $0.887^{\star *}$ & 1.000 & $0.880^{* *}$ & $0.865^{\star *}$ & $0.865^{\star *}$ \\
\hline 8. Curriculum assessment & $0.834^{\star *}$ & $0.850^{\star *}$ & $0.853^{\star *}$ & $0.851^{\star *}$ & $0.849^{* *}$ & $0.863^{\star *}$ & $0.880^{\star *}$ & 1.000 & $0.879^{\star *}$ & $0.864^{\star *}$ \\
\hline 9. Teaching feedback & $0.826^{\star *}$ & $0.839^{* *}$ & $0.845^{\star *}$ & $0.844^{\star *}$ & $0.848^{\star *}$ & $0.855^{\star *}$ & $0.865^{\star *}$ & $0.879^{\star *}$ & 1.000 & $0.878^{\star *}$ \\
\hline 10. Curriculum satisfaction & $0.822^{\star *}$ & $0.846^{\star *}$ & $0.846^{\star *}$ & $0.848^{\star *}$ & $0.847^{\star *}$ & $0.853^{\star *}$ & $0.865^{\star *}$ & $0.864^{\star *}$ & $0.878^{\star *}$ & 1.000 \\
\hline
\end{tabular}

Note: ${ }^{*}$ When the confidence (bilateral) is 0.01 , the correlation is significant.

so correlation analysis of spearman is used. There is correlation between the ten dimensions of curriculum teaching, and the correlation coefficients are greater than $0.8, \mathrm{P}=0.000<0.05$, indicating that there is a strong correlation between the ten dimensions of curriculum teaching.

\section{Regression Analysis}

Taking teaching feedback, degree of difficulty, teaching means, teaching organization, class evaluation, curriculum resources, teacher-student interaction, curriculum assessment, curriculum ideological and political as independent variables and curriculum satisfaction as dependent variables, the constructed model has statistical significance, as shown in Table 4 and Table 5, P = 0.000, $R=0.904, \mathrm{R}^{2}$ $=0.817$. It can explain $81.7 \%$ of curriculum satisfaction. As can be seen from 
Table 4. Model summaryb.

\begin{tabular}{cccccc}
\hline Model & R & R square & $\begin{array}{c}\text { Adjust } \mathbf{R} \\
\text { square }\end{array}$ & $\begin{array}{c}\text { Error of } \\
\text { standard estimation }\end{array}$ & Durbin-Watson \\
\hline 1 & $0.904^{\mathrm{a}}$ & 0.817 & 0.816 & 0.284 & 1.970 \\
\hline
\end{tabular}

aPredictive variables: (constant), teaching feedback, degree of difficulty, teaching means, teaching organization, class evaluation, curriculum resources, teacher-student interaction, curriculum assessment, curriculum ideological and political. ${ }^{b}$ Dependent variable: curriculum satisfaction.

Table 5. Anovab.

\begin{tabular}{ccccccc}
\hline \multicolumn{1}{l}{ Model } & Sum of squares & df & mean square & F & Sig. \\
\hline & regression & 2050.274 & 9 & 227.808 & 2831.444 & $0.000^{\mathrm{a}}$ \\
1 & residual & 460.292 & 5721 & 0.080 & & \\
& total & 2510.566 & 5730 & & & \\
\hline
\end{tabular}

aPredictive variables: (constant), teaching feedback, degree of difficulty, teaching means, teaching organization, class evaluation, curriculum resources, teacher-student interaction, curriculum assessment, curriculum ideological and political. ${ }^{b}$ Dependent variable: curriculum satisfaction.

Table 6. Coefficient ${ }^{\mathrm{a}}$.

\begin{tabular}{|c|c|c|c|c|c|c|}
\hline & \multirow[t]{2}{*}{ Model } & \multicolumn{2}{|c|}{ Non standardized coefficient } & \multirow{2}{*}{$\begin{array}{c}\text { standardized } \\
\text { coefficient }\end{array}$} & \multirow[t]{2}{*}{$\mathrm{t}$} & \multirow[t]{2}{*}{ Sig. } \\
\hline & & B & Standard error & & & \\
\hline \multirow{10}{*}{1} & (constant) & 0.067 & 0.028 & & 2.371 & 0.018 \\
\hline & Degree of difficulty & 0.027 & 0.013 & 0.027 & 2.058 & 0.040 \\
\hline & $\begin{array}{l}\text { Curriculum ideological } \\
\text { and political }\end{array}$ & 0.122 & 0.014 & 0.120 & 8.449 & 0.000 \\
\hline & $\begin{array}{l}\text { Teachers-students } \\
\text { interaction }\end{array}$ & 0.048 & 0.014 & 0.048 & 3.400 & 0.001 \\
\hline & Class evaluation & 0.094 & 0.014 & 0.093 & 6.787 & 0.000 \\
\hline & Teaching means & 0.061 & 0.013 & 0.062 & 4.800 & 0.000 \\
\hline & Curriculum resources & 0.061 & 0.014 & 0.061 & 4.490 & 0.000 \\
\hline & Teaching organization & 0.147 & 0.014 & 0.148 & 10.608 & 0.000 \\
\hline & Curriculum assessment & 0.142 & 0.014 & 0.141 & 10.163 & 0.000 \\
\hline & Teaching feedback & 0.278 & 0.013 & 0.272 & 20.630 & 0.000 \\
\hline
\end{tabular}

aDependent variable: curriculum satisfaction.

Table 6, the constructed prediction model is shown in formula (2) (Chen \& Xie, 2020; Wu Ying, Yao Li, Hu Kun-Hong, \& Gao Da-Ming, 2020; Zheng-Yan Shi, Xiao-Ling Li, Meng-Yan Tang et al., 2020).

$$
\begin{aligned}
Y= & 0.067+0.027 \times X_{1}+0.122 \times X_{2}+0.048 \times X_{3}+0.094 \times X_{4}+0.061 \times X_{5} \\
& +0.061 \times X_{6}+0.147 \times X_{7}+0.142 \times X_{8}+0.278 \times X_{9}
\end{aligned}
$$

\section{Suggestions for Improvement}

Combined with the data analysis of teaching quality evaluation and the existing 
problems, according to the characteristics of professional curriculum, the following suggestions are put forward.

1) In terms of classroom interaction, it is suggested that teachers should carry out more classroom interaction in combination with the curriculum content, instead of simple Q \& A, use a variety of teaching methods, design rich classroom interaction links, improve students' classroom participation, enhance teachers' timely understanding of students' learning and guide teaching through classroom questioning.

2) In terms of homework, teachers are required to reasonably arrange afterschool exercises according to the school's arrangement requirements for homework and in combination with teaching characteristics, so as to help students consolidate their learning contents, and give feedback and guidance according to students' practice.

3) As for the curriculum content, it is suggested that teachers should provide more teaching examples in combination with the characteristics of professional curriculum, and give more practical guidance for curriculum with strong operability, so as to improve students' understanding and practical application ability.

4) For some curriculum with certain difficulties, students need more time to think and teachers need appropriate after-school guidance. Further guidance can be provided through network communication, online Q \& A, video explanation and offline guidance to improve students' mastery of teaching content.

\section{Conclusion}

According to the curriculum satisfaction model, appropriately increase the curriculum of ideological and political education, carefully prepare the teaching organization, improve course assessment, highlight and strengthen process course assessment, increase the teaching feedback of each link, make students' evaluation of the course further meet their satisfaction and improve students' satisfaction with the course.

\section{Acknowledgements}

Project supported by the research on teaching reform of Nanchang Normal University (Grant No. JGKT-19-12) and also by Training program for college students (Grant No.201914437012, 201914437013).

\section{Conflicts of Interest}

The author declares no conflicts of interest regarding the publication of this paper.

\section{References}

Chen, R., \& Xie, F. J. (2020). Research on the Influencing Factors of College Students' Labor Education. Open Access Library Journal, 7, e7073.

https://doi.org/10.4236/oalib.1107073 
Shi, Z.-Y., Li, X.-L., Tang, M.-Y. et al. (2020). Investigation and Analysis of Undergraduate Nursing Students' Attitudes toward Advanced Care Planning and Their Willingness to Implement. American Journal of Hospice and Palliative Medicine, 37, 613-618. https://doi.org/10.1177/1049909120902123

Wu, Y., Yao L., Hu, K.-H., \& Gao, D.-M. (2020). Evaluation and Practice on Analytical Chemistry Course Quality Based on OBE Concept. Journal of Hefei University (Comprehensive Edition), 37, 140-144. 